\title{
Abdominal effects of laparoscopic surgery
}

\author{
Hüseyin Kerem Tolan, Fikret Ezberci \\ Department of General Surgery, Health Sciences University Ümraniye Training and Research Hospital, İstanbul, Turkey
}

\begin{abstract}
Pneumoperitoneum (PNP) is very commonly performed in surgical practice due to the extensive use of laparoscopic surgery. In minimally invasive surgery, there is an effort to convert all eligible surgical procedures to a laparoscopic technique, as it has fewer systemic and local surgical effects on the patient. During PNP, intraperitoneal pressure (IPP) is increased to well above normal intra-abdominal pressure in order to create an opening for visualization of the abdominal contents. The duration of these procedures can be prolonged as a result of the difficulties and complexities of these techniques. IPP has side effects on the physiology of patients, as is seen in abdominal compartment syndrome.
\end{abstract}

Keywords: Abdominal viscera; compartment syndrome; intra-abdominal pressure; laparoscopy; pneumoperitoneum.

\section{Introduction}

Pneumoperitoneum (pneuma: air; peri: around; teinein: to stretch) is a Greek word defining the presence of gas within the peritoneal cavity. The physiology of pneumoperitoneum (PNP) has been considered synonymously with the physiology of laparoscopy \& refers to the physiological changes associated with the intraperitoneal carbon dioxide (CO2) insufflations that has both local and systemic effects. The laparoscopic approach to surgery may involve limited abdominal access but causes less systemic stress and a better acute-phase response. ${ }^{[1,2]}$

Laparoscopic surgery (LS) has become a valuable tool in general surgery following the success of laparoscopic cholecystectomy which has many advantages over the conventional cholecystectomy. ${ }^{[3]}$ The use of minimally invasive techniques have been shown to decrease the postoperative pain, causing less sympathetic response leading to less postoperative ileus, decreased respiratory distress, diminished hospital stay and more rapid return to preoperative physical activities. ${ }^{[3,4]}$ Studies have shown that LS minimizes the surgical trauma, as demonstrated by the diminished release of acute inflammatory markers, fast return of cytokine levels to normal values and lower cortisol levels. The immune function is also better preserved in LS. ${ }^{[5-9]}$ Possibly the most important factor is reduced surgical trauma due to the use of small incisions and minimally traumatic operative techniques. ${ }^{[10]}$

Tissue injury induced by LS is qualitatively different from the open surgery. ${ }^{[1,12]}$ In the open surgery most important components of injury are the amount of injured tissue (wound size), visceral traction, desication and temperature changes. During LS the injury related to the wound is reduced, but other components may develop either as a consequence of abdominal wall and peritoneal distension or in relation to the type of the gas used and the dura- 
tion of the procedure. ${ }^{[13]}$ Animal studies show that intestinal recovery is faster after laparoscopic procedures than the open procedures. ${ }^{[14-17]}$ Decreased bowel manipulation and associated inflammation are likely the explanations for these findings, although other considerations may include the minimizing exposure of bowel to the hostile, nonphysiologic environment accompanying laparotomy, which may later alter the motility. ${ }^{[18,19]}$

\section{Peritoneum;}

The peritoneum is a single continuous layer of mesothelial cells 2.5 to $3 \mu \mathrm{m}$ thick which is covered with microvilli. ${ }^{[20]}$ These cells, joined by tight junctions and desmosomes, rest on a basement membrane, below which is a layer of fibrous connective tissue. The normal peritoneal cavity contains less than $100 \mathrm{ml}$ of serous fluid, which is essentially an ultrafiltrate of plasma with a protein concentration less than $3 \mathrm{~g} / \mathrm{dl}^{\left[{ }^{[21]}\right.}$ The peritoneum usually contains fewer than 300 cells $/ \mathrm{mm}^{3}$, mostly macrophages, some desquamated mesothelial cells and lymphocytes. Peritoneal macrophages are integral to the primary inflammatory response generated in the abdominal cavity in response to infection and cancer. Macrophages also are implicated in the regulation of the acute phase response and the release of the monokines interleukin-1 (IL-1), IL-6, TNF-alfa, and arachidonic acid metabolites. ${ }^{[21-23]}$ The creation of a $\mathrm{CO} 2$ PNP induces morphologic changes in the peritoneal mesothelial surface layer, which are visible microscopically. [24] This includes bulging of mesothelial cells, widening of intercellular junctions, cellular burgeoning and exposure of the basement membrane underneath it.Structural alterations in the mesothelial lining, $\mathrm{pH}$ disturbances and alterations in peritoneal macrophage responsiveness. ${ }^{[25]}$

CO2 induces marked tissue acidification and reduces cell $\mathrm{pH}$ of cells in the peritoneum, such as macrophages and mesothelial cells. This could be attributable to the use of $\mathrm{CO} 2$ or it might be attributable to the desiccation of the peritoneal surface by cold insufflation of the gas. ${ }^{[26-29]}$

\section{Carbon Dioxide (CO2)}

In the LS abdominal wall is distended via PNP to provide room for the instrument insertion and tissue dissection.

CO2 insufflation is commonly used for the creation of PNP which requires impurity of less than 200 parts per million, including water vapor. ${ }^{[30,31]}$ Zöllikoffer, in 1926 first proposed the use of $\mathrm{CO} 2$ as an insufflating agent, but its use became firmly established only after the development of the automated peritoneal insufflator by Kurt Semm in the 1960s. ${ }^{[32,33]}$ CO2 is supplied in liquid form from cylinders with a release temperature of approximately $90^{\circ} \mathrm{C} .{ }^{[25]}$ The passage of $\mathrm{CO} 2$ through the insufflator and tubing apparatus raises this temperature to approximately room temperature $\left(19^{\circ} \mathrm{C}-21^{\circ} \mathrm{C}\right)$ at the point of delivery to the peritoneal cavity with a relative humidity approaching $0 \%$ at the point of entry into the peritoneal cavity. ${ }^{[34-36]}$ However, this still is significantly lower than the normal intraperitoneal or core temperature. Large volumes of gas may be required for a single patient (up to 500 litres), owing to the imperfect seal of the laparoscopic ports and peritoneal $\mathrm{CO} 2$ absorption. Prolonged insufflation with $\mathrm{CO} 2$ is associated with a reduction in body temperature as well as the intraperitoneal humidity. ${ }^{[25,34,37]}$ The disadvantages of peri-operative hypothermia are well known and includes increased rates of postoperative infection, increased cardiac output and prolonged postoperative recovery ${ }^{[25]}$ With respect to the desiccation and temperature factors, there are potential added benefits of using warmed and humidified CO2. ${ }^{[1]}$ Several advantages of CO2, such as its rapid absorption and elimination, have contributed to its frequent use as the insufflating gas for exposure in LS. ${ }^{[31,38]}$ $\mathrm{CO} 2$ is inexpensive, noncombustible, colorless, odorless, tasteless, and nontoxic. It is a natural component of the atmosphere $(0.035 \%)$ and it is part of the basic cycle of life (the product of breathing, fermentation, and combustion). $\mathrm{CO} 2$ also is recognized for its wide physicochemical properties (it is nonexplosive, noncorrosive, nonconductive, and nonpolluting) and for being an inert gas. İt is excreted by the lungs during normal respiration and is highly soluble in water, which reduces the risk of gas embolism impairing cardiac function. ${ }^{[39,40]}$

Recent evidence suggests that the use of continuous flow of cool, dry CO2 to create a PNP during laparoscopy does not simply create a working space for surgery, but can also lead to adverse structural, metabolic, and immune dearrangements within the peritoneal mesothelial layer and that these can be dependent on the specific insufflation of the gas used. ${ }^{[25,31,38,41-43]}$ How much of this effect relates to intrinsic properties of $\mathrm{CO} 2$, and how much is due to the desiccative effect of the gas is not clear. ${ }^{[37,44]}$ Another possible component of injury is the impact on microcirculation due to the increased intraperitoneal pressure (IPP) at both the parietal (subperitoneal) and the visceral level. ${ }^{[45]}$ These effects could be due to the metabolic complications from the transperitoneal absorption of $\mathrm{CO} 2$ and/or elevated IPP. ${ }^{[1]}$ 
There are four major stressors on the physiologic status of the patient during the LS:

(a) hypercarbia and acidemia from absorbed $\mathrm{CO} 2$

(b) elevated IPPs,

(c) exaggerated positional placements of the patient, and

(d) general surgical stress.

When advanced and lengthy laparoscopic procedures are performed in older patients, long-term cardiac, pulmonary and renal diseases may also contribute to the compromise of physiologic functions, further lowering thresholds for major complications under surgical stress. Minor physiologic changes in a healthy patient may become major significant changes in patients who present with compromised functions. ${ }^{[46,47]}$

\section{Pneumoperitoneum;}

The CO2 PNP exerts its physiologic effects via two different mechanisms; ${ }^{[48]}$

1. Mechanical effects relating to increased IPP,

2. Chemical effect of the gas used for insufflation, which is mostly $\mathrm{CO} 2$.

These two phenomena coupled with the position of patient (head-up or head-down), affects the body physiology in multiple aspects including hemodynamic, metabolic and respiratory changes. ${ }^{[49]}$

\section{Intraperitoneal Pressure (IPP)}

Due to the insufflation of the peritoneal cavity to obtain the endoscopic exposure, these patients are being subjected to an artificially elevated IPP for several hours. ${ }^{[50]}$ Although working PNP pressures vary gas insufflations causes an increase in the IPP. Most procedures are performed at a pressure of 10 to $15 \mathrm{mmHg}$. This pressure range, although greater than the normal portal systemic pressure $(7-10 \mathrm{mmHg}$ ), maintains the balance between establishment of a working space and the unwanted effects of increased IPP. ${ }^{[51]}$

Laplace's law well describes the effect of PNP on pressure across the abdominal wall which explains that the higher the tension on the abdominal wall, the higher the intra-abdominal pressure for a given fixed radius at maximal abdominal expansion. ${ }^{[52]}$ This pressure reduces peritoneal microcirculation during laparoscopy, in addition to the systemic haemodynamic effect. ${ }^{[3,54]}$
The term intraabdominal hypertension is usually defined as an IPP of $12 \mathrm{mmHg}$ or more. ${ }^{[55]}$ The adverse effects of this elevated IPP on the systemic circulation and cardiac, pulmonary, and renal functions have been well documented in clinical studies. ${ }^{[56,57]}$ Studies have illustrated that an increase in IPP affects the perfusion of many abdominal organs. This is a pressure-related phenomenon. ${ }^{[2]}$

Reduced venous return and the reduction in cardiac output and accompanying mesenteric vasoconstriction and increased systemic vascular resistance has been reported to cause a significant reduction in organ perfusion and portal venous flow during the increase in IPP. ${ }^{[0,58-61]}$ The vasoconstrictive effect of $\mathrm{CO} 2$ also causes reduced visceral blood flow. ${ }^{[48]}$

The normal mean IPP is zero or less and a clinically significant elevation of IPP up to 10 to $15 \mathrm{mmHg}$ significantly decreases the abdominal splanchnic blood flow. For example blood flow in abdominal hypertension decreases in the stomach by 40 per cent, duodenum by 11 per cent, jejunum by 32 per cent, colon by 44 per cent, liver by 39 per cent and the parietal peritoneum by 60 per cent. ${ }^{[50,58,59]}$ In an animal model, increased IPPs of 10 and $20 \mathrm{mmHg}$ caused a respective decrease of $20 \%$ and $40 \%$ in mucosal blood flow in the small intestine. ${ }^{[62]}$ Splanchnic perfusion changes are the result of a complex interaction between anaesthesia, the surgical insult, patient position and the nature of the gas used. Splanchnic blood flow also decreases significantly with operating time at a constant IPP. ${ }^{[59]}$ Changes in the splanchnic circulation such as decreased mucosal blood flow have been reported in animal experiments. ${ }^{[50]}$ PNP also decreases the hepatic blood flow, but effects of an elevated IPP on the flow to the liver in the human is uncertain. ${ }^{[48,63]}$ However, it appears that intestinal blood flow, when measured with the microsphere technique, displays minimal change during PNP of $15 \mathrm{mmHg}{ }^{[51]}$ In addition, there was a significant reduction in gastric mucosal $\mathrm{pH}$ in patients undergoing laparoscopic cholecystectomy when an insufflation pressure of 12-15 mmHg was used compared with 4-8 mmHg. ${ }^{[64]}$ There are several reports of mesenteric ischaemia and bowel infarction after routine laparoscopic procedures. ${ }^{[65,66]}$ Incision or breaching of the peritoneum is considered as a significant inducer of operative stress. Together with exposure of the bowel or peritoneum to atmospheric air during the open procedures, it may be sufficient to have an impact on the gut mucosal immune response and subsequent postoperative recovery. Most of the laparoscopic procedures that 
clearly show benefits to clinical postoperative recovery are performed entirely by laparoscopy without breaching the peritoneum and bowel exposure to atmosphere. [1] Increased IPP is an important cause of gastrointestinal ischemia. ${ }^{[58,67]}$ Impaired perfusion of splanchnic organs secondary to increased IPP and their reperfusion after the procedure represent ischemia and reperfusion (I/R) respectively. I/R injury is responsible for most of the damage complicating reversible arterial insufficiency of the intestine, provided that there is no venous congestion. ${ }^{[62,68]} \mathrm{I} / \mathrm{R}$ injury impairs anastomotic healing in the bowel and is the most likely mechanism of the detrimental effect of the high IPPs on colonic anastomoses reported. ${ }^{[69,70]}$ Intestinal I/R injury leads to oxidative stress, which propagates further injury. Pressure-induced $I / R$ injury in the intestine is reflected by the increased oxidative enzyme activity and oxidant generation of intestinal tissue after pressure. ${ }^{[71,72]}$ Intestinal oxidative stress associated with pressure was described initially by Eleftheriadis et al. ${ }^{[73]}$ Nitric oxide (NO) is a reactive compound produced via the activity of different NO synthase (NOS) isoenzymes that can be synthesized in the intestine. ${ }^{[74]}$ It is both an indicator and an effector of oxidative stress. However, many beneficial roles have also been attributed to NO particularly within the context of vascular homeostasis. ${ }^{[75]}$ Ischemia of splanchnic organs, including the intestine during pressure and their subsequent and sometimes paradoxically increased reperfusion after pressure can cause $I / R$ injury. ${ }^{[68,73]}$ Pressure-associated intestinal I/R injury has important implications, as reflected by clinical reports of lethal intestinal ischemia after laparoscopy and with the reports demonstrating the decreased strength and healing of colocolonic anastomoses in rats after a high-pressure procedure. ${ }^{[69,70]}$ The relation between intestinal I/R injury and oxidative stress was further characterized by Takada et al., who reported that intestine subjected to mesenteric artery occlusion followed by reperfusion, developed $\mathrm{mu}$ cosal damage that is correlated with increased local production of $\mathrm{NO}$ and metabolites, nonselective inhibitor of NOS, L-NAME. ${ }^{[72]}$ The intestine acts as a barrier to the luminal contents, which include bacteria and the endotoxins. The gut barrier is altered in certain pathologic conditions such as shock, trauma or surgical stress; resulting in bacterial or endotoxin translocation from the gut lumen into the systemic circulation. ${ }^{[7]}$ This has been implicated in postoperative complications, such as systemic inflammatory response syndrome and multiorgan failure. ${ }^{[77]} \mathrm{LS}$ presents reduced postoperative infections. ${ }^{[78,79]}$ In the lap- arotomy technique, the peritoneum is manipulated, the small intestine is handled and the mesentery is placed under traction; while in the laparoscopic approach these are minimized. These factors, which are integral parts of the laparotomic approach, may lead to the production of vasoactive agents that can cause both local and systemic hemodynamic changes. ${ }^{[12,80]}$

The mucosa of the intestine and the endothelium of blood vessels contain enzymes capable of synthesizing prostaglandins and the production of these may be initiated by neural, ischemic, toxic or mechanical stimuli. ${ }^{[81]}$ The generation of these vasoactive prostaglandins can therefore induce splanchnic ischemia with subsequent disruption of mucosal integrity and leading to increased intestinal permeability. Therefore, intestinal manipulation may lead to the endotoxemia that can be detected in the systemic circulation of patients undergoing cholecystectomy. This agrees with the hypothesis that intestinal manipulation may impair intestinal mucosal barrier function and leading to the systemic inflammatory response seen in open chlecystectomies. ${ }^{[78]}$ Most experimental evidence suggests that the changes in the intraperitoneal environment are CO2-specific effects. CO2-induced acidification at the peritoneal surface may mediate suppression of peritoneal macrophage function. ${ }^{[25]}$ Also the local acidity caused by the $\mathrm{CO} 2$ being converted to carbonic acid in the peritoneal fluid results in microscopically visible histological damage to the mesothelial ultrastructure which is more pronounced when the peritoneum is exposed to room air in laparotomies. ${ }^{[31,43]}$ The underlying philosophy of LS is not only to create a minimal access" surgical environment, but also to be minimally disruptive" to the patient. ${ }^{[25]}$ In order to reduce these haemodynamic changes it is recommended that the lowest possible inflation pressure is used, with insufflation started at a standard pressure (12-15 mmHg) and then the pressure is gradually lowered down as much as possible without compromising the visibility as in the dial-down' approach. ${ }^{[70,82]}$ Some have also advocated releasing gas intermittently during the procedure. ${ }^{[83]}$

\section{Disclosures}

Peer-review: Externally peer-reviewed.

Conflict of Interest: None declared.

\section{References}

1. Luk JM, Tung PH, Wong KF, Chan KL, Law S, Wong J. Laparoscopic surgery induced interleukin-6 levels in serum and gut 
mucosa: implications of peritoneum integrity and gas factors. Surg Endosc 2009;23:370-6. [CrossRef]

2. Pappas TN, Fecher AM. Principles of minimally invasive surgery. Norton J, Barie PS, Bollinger RR, Chang AE, Lowry S, Mulvihill SJ, et al editors. Basic Science and Clinical Evidence. 2nd ed. New York: Springer; 2008. p. 771-90. [CrossRef]

3. Targarona EM, Rodríguez M, Camacho $M$, Balagué $C$, Gich I, Vila L, et al. Immediate peritoneal response to bacterial contamination during laparoscopic surgery. Surg Endosc 2006;20(2):316-21. [CrossRef]

4. Rosenblatt A, Bollens R, Espinoza Cohen B. Fundamentals of Laparoscopic Surgery. In: Manuel of Laparoscopic Surgery. Springer Berlin; 2008. p. 3-17.

5. Buunen M, Gholghesaei M, Veldkamp R, Meijer DW, Bonjer HJ, Bouvy ND. Stress response to laparoscopic surgery: a review. Surg Endosc 2004;18:1022-8. [CrossRef]

6. Novitsky YW, Litwin DE, Callery MP. The net immunologic advantage of laparoscopic surgery. Surg Endosc 2004;18:1411-9. [CrossRef]

7. Sietses C, von Blomberg ME, Eijsbouts QA, Beelen RH, Berends FJ, Cuesta MA. The influence of $\mathrm{CO} 2$ versus helium insufflation or the abdominal wall lifting technique on the systemic immune response. Surg Endosc 2002;16:525-8.

8. Sylla P, Kirman I, Whelan RL. Immunological advantages of advanced laparoscopy. Surg Clin North Am 2005;85:1-18.

9. Targarona EM, Pons MJ, Balagué C, Espert JJ, Moral A, Martínez $\mathrm{J}$, et al. Acute phase is the only significantly reduced component of the injury response after laparoscopic cholecystectomy. World J Surg 1996;20:528-33. [CrossRef]

10. Bouvy ND, Giuffrida MC, Tseng LN, Steyerberg EW, Marquet $\mathrm{RL}$, Jeekel $\mathrm{H}$, et al. Effects of carbon dioxide pneumoperitoneum, air pneumoperitoneum, and gasless laparoscopy on body weight and tumor growth. Arch Surg 1998;133:652-6.

11. Brodsky JA, Brody FJ, Endlich B, Armstrong DA, Ponsky JL, Hamilton IA. MCP-1 is highly expressed in peritoneum following midline laparotomy with peritoneal abrasion in a murine model. Surg Endosc 2002;16:1079-82. [CrossRef]

12. Kalff JC, Türler A, Schwarz NT, Schraut WH, Lee KK, Tweardy DJ, et al. Intra-abdominal activation of a local inflammatory response within the human muscularis externa during laparotomy. Ann Surg 2003;237:301-15. [CrossRef]

13. Bachman SL, Hanly EJ, Nwanko JI, Lamb J, Herring AE, Marohn MR, et al. The effect of timing of pneumoperitoneum on the inflammatory response. Surg Endosc 2004;18:1640-4.

14. Böhm B, Milsom JW, Fazio VW. Postoperative intestinal motility following conventional and laparoscopic intestinal surgery. Arch Surg 1995;130:415-9. [CrossRef]

15. Davies W, Kollmorgen CF, Tu QM, Donohue JH, Thompson GB, Nelson $\mathrm{H}$, et al. Laparoscopic colectomy shortens postoperative ileus in a canine model. Surgery 1997;121:550-5.

16. Hotokezaka M, Combs MJ, Mentis EP, Schirmer BD. Recovery of fasted and fed gastrointestinal motility after open versus laparoscopic cholecystectomy in dogs. Ann Surg 1996;223:413-9. [CrossRef]

17. Carroll J, Alavi K. Pathogenesis and management of postop- erative ileus. Clin Colon Rectal Surg 2009;22:47-50. [CrossRef]

18. Norwood MG, Lykostratis H, Garcea G, Berry DP. Acute colonic pseudo-obstruction following major orthopaedic surgery. Colorectal Dis 2005;7:496-9. [CrossRef]

19. Jørgensen H, Wetterslev J, Møiniche S, Dahl JB. Epidural local anaesthetics versus opioid-based analgesic regimens on postoperative gastrointestinal paralysis, PONV and pain after abdominal surgery. Cochrane Database Syst Rev 2000:CD001893.

20. Slater NJ, Raftery AT, Cope GH. The ultrastructure of human abdominal mesothelium. J Anat 1989;167:47-56.

21. Rofe AM, Bourgeois CS, Coyle P. Beneficial effects of endotoxin treatment on metabolism in tumour-bearing rats. Immunol Cell Biol 1992;70:1-7. [CrossRef]

22. Jones AL, Selby P. Clinical applications of tumour necrosis factor. Prog Growth Factor Res 1989;1:107-22. [CrossRef]

23. Redmond HP, Hofmann K, Shou J, Leon P, Kelly CJ, Daly JM. Effects of laparotomy on systemic macrophage function. Surgery 1992;111:647-55.

24. Schaeff B, Paolucci V, Henze A, Schlote W, Encke A. Electron microscopy change in the peritoneum after laparoscopic operations. Langenbecks Arch Chir Suppl Kongressbd 1998;115:571-3.

25. Neuhaus SJ, Watson DI. Pneumoperitoneum and peritoneal surface changes: a review. Surg Endosc 2004;18:1316-22.

26. Kopernik G, Avinoach E, Grossman Y, Levy R, Yulzari R, Rogachev $B$, et al. The effect of a high partial pressure of carbon dioxide environment on metabolism and immune functions of human peritoneal cells-relevance to carbon dioxide pneumoperitoneum. Am J Obstet Gynecol 1998;179:1503-10.

27. Kuntz C, Wunsch A, Bödeker C, Bay F, Rosch R, Windeler J, et al. Effect of pressure and gas type on intraabdominal, subcutaneous, and blood pH in laparoscopy. Surg Endosc 2000;14:367-71. [CrossRef]

28. Ure BM, Niewold TA, Bax NM, Ham M, van der Zee DC, Essen GJ. Peritoneal, systemic, and distant organ inflammatory responses are reduced by a laparoscopic approach and carbon dioxide versus air. Surg Endosc 2002;16:836-42. [CrossRef]

29. Wildbrett P, Oh A, Naundorf D, Volk T, Jacobi CA. Impact of laparoscopic gases on peritoneal microenvironment and essential parameters of cell function. Surg Endosc 2003;17:7882. [CrossRef]

30. de Barros CJ, Sobrinho JA, Rapoport A, Novo NF, Azevedo $\mathrm{JL}$, Sorbello A. Comparative study of the changes in partial pressure of plasma carbon dioxide during carbon dioxide insufflation into the intraperitoneal and preperitoneal spaces. J Laparoendosc Adv Surg Tech A 2009;19:345-9. [CrossRef]

31. Neuhaus SJ, Gupta A, Watson DI. Helium and other alternative insufflation gases for laparoscopy. Surg Endosc 2001;15:553-60. [CrossRef]

32. Cushieri A, Buess G. Introduction and historical aspects. In: Cushieri A, Buess G, Perissat J, editors. Operative manual of endoscopic surgery. New York: Springer Verlag; 1992. p. 1-5.

33. Lau WY, Leow CK, Li AK. History of endoscopic and laparoscopic surgery. World J Surg 1997;21:444-53. [CrossRef] 
34. Puttick MI, Scott-Coombes DM, Dye J, Nduka CC, Menzies-Gow NM, Mansfield AO, et al. Comparison of immunologic and physiologic effects of $\mathrm{CO} 2$ pneumoperitoneum at room and body temperatures. Surg Endosc 1999;13:572-5.

35. Sammour T, Kahokehr A, Hill AG. Meta-analysis of the effect of warm humidified insufflation on pain after laparoscopy. $\mathrm{Br}$ J Surg 2008;95:950-6. [CrossRef]

36. Davis SS, Mikami DJ, Newlin M, Needleman BJ, Barrett MS, Fries $\mathrm{R}$, et al. Heating and humidifying of carbon dioxide during pneumoperitoneum is not indicated: a prospective randomized trial. Surg Endosc 2006;20:153-8. [CrossRef]

37. Hazebroek EJ, Schreve MA, Visser P, De Bruin RW, Marquet $\mathrm{RL}$, Bonjer HJ. Impact of temperature and humidity of carbon dioxide pneumoperitoneum on body temperature and peritoneal morphology. J Laparoendosc Adv Surg Tech A 2002;12:355-64. [CrossRef]

38. Yilmaz S, Ates E, Polat C, Koken T, Tokyol C, Akbulut G, et al. Ischemic preconditioning decreases laparoscopy-induced oxidative stress in small intestine. Hepatogastroenterology 2003;50:979-82.

39. Sorbello AA, Azevedo JL, Osaka JT, Damy S, França LM, Tolosa EC. Protective effect of carbon dioxide against bacterial peritonitis induced in rats. Surg Endosc 2010;24:1849-53.

40. von Delius S, Sager J, Feussner H, Wilhelm D, Thies P, Huber W, et al. Carbon dioxide versus room air for natural orifice transluminal endoscopic surgery (NOTES) and comparison with standard laparoscopic pneumoperitoneum. Gastrointest Endosc 2010;72:161-9. [CrossRef]

41. Erikoglu M, Yol S, Avunduk MC, Erdemli E, Can A. Electron-microscopic alterations of the peritoneum after both cold and heated carbon dioxide pneumoperitoneum. J Surg Res 2005;125:73-7. [CrossRef]

42. Sammour T, Mittal A, Loveday BP, Kahokehr A, Phillips AR, Windsor JA, et al. Systematic review of oxidative stress associated with pneumoperitoneum. Br J Surg 2009;96:83650. [CrossRef]

43. Rosário MT, Ribeiro U Jr, Corbett CE, Ozaki AC, Bresciani $\mathrm{CC}$, Zilberstein B, et al. Does CO2 pneumoperitoneum alter the ultra-structuture of the mesothelium? J Surg Res 2006;133:84-8. [CrossRef]

44. Bergström M, Falk P, Park PO, Holmdahl L. Peritoneal and systemic $\mathrm{pH}$ during pneumoperitoneum with $\mathrm{CO} 2$ and helium in a pig model. Surg Endosc 2008;22:359-64. [CrossRef]

45. Bentes de Souza AM, Wang CC, Chu CY, Briton-Jones CM, Haines CJ, Rogers MS. In vitro exposure to carbon dioxide induces oxidative stress in human peritoneal mesothelial cells. Hum Reprod 2004;19:1281-6. [CrossRef]

46. Chang CK, Zdon MJ. Inflammatory response of interleukin-1beta and interleukin- 6 in septic rats undergoing laparotomy and laparoscopy. Surg Laparosc Endosc Percutan Tech 2005; 15:124-8. [CrossRef]

47. Wortel $\mathrm{CH}$, van Deventer SJ, Aarden LA, Lygidakis $\mathrm{NJ}$, Büller HR, Hoek FJ, et al. Interleukin-6 mediates host defense responses induced by abdominal surgery. Surgery 1993;114:564-70.
48. Arif Ahmad, Bruce D. Schirmer. Summary of Intraoperative Physiologic Alterations Associated with Laparoscopic Surgery. In: Whelan RL, Fleshman JW, Fowler D, editors. SAGES Manual. New York: Springer; 2006. p. 56-62. [CrossRef]

49. Girardis M, Da Broi U, Antonutto G, Pasetto A. The effect of laparoscopic cholecystectomy on cardiovascular function and pulmonary gas exchange. Anesth Analg 1996;83:13440. [CrossRef]

50. Jakimowicz J, Stultiëns G, Smulders F. Laparoscopic insufflation of the abdomen reduces portal venous flow. Surg Endosc 1998;12:129-32. [CrossRef]

51. Goitein D, Papasavas P, Yeaney W, Gagne D, Hayetian F, Caushaj $P$, et al. Microsphere intestinal blood flow analysis during pneumoperitoneum using carbon dioxide and helium. Surg Endosc 2005;19:541-5. [CrossRef]

52. http://www.merriam-webster.com/medlineplus/law+of+laplace. Accessed Jun 20, 2014.

53. Bentes de Souza AM, Rogers MS, Wang CC, Yuen PM, Ng PS. Comparison of peritoneal oxidative stress during laparoscopy and laparotomy. J Am Assoc Gynecol Laparosc 2003;10:65-74. [CrossRef]

54. Ishizaki $Y$, Bandai $Y$, Shimomura $K$, Abe H, Ohtomo $Y$, Idezuki Y. Safe intraabdominal pressure of carbon dioxide pneumoperitoneum during laparoscopic surgery. Surgery 1993;114:549-54.

55. An G, West MA. Abdominal compartment syndrome: a concise clinical review. Crit Care Med 2008;36:1304-10. [CrossRef]

56. Kotzampassi K, Kapanidis N, Kazamias P, Eleftheriadis E. Hemodynamic events in the peritoneal environment during pneumoperitoneum in dogs. Surg Endosc 1993;7:494-9.

57. Westerband A, Van De Water J, Amzallag M, Lebowitz PW, Nwasokwa ON, Chardavoyne R, et al. Cardiovascular changes during laparoscopic cholecystectomy. Surg Gynecol Obstet 1992;175:535-8.

58. Eleftheriadis E, Kotzampassi K, Botsios D, Tzartinoglou E, Farmakis H, Dadoukis J. Splanchnic ischemia during laparoscopic cholecystectomy. Surg Endosc 1996;10:324-6. [CrossRef]

59. Schilling MK, Redaelli C, Krähenbühl L, Signer C, Büchler MW. Splanchnic microcirculatory changes during CO2 laparoscopy. J Am Coll Surg 1997;184:378-82.

60. Dexter SP, Vucevic M, Gibson J, McMahon MJ. Hemodynamic consequences of high- and low-pressure capnoperitoneum during laparoscopic cholecystectomy. Surg Endosc 1999;13:376-81. [CrossRef]

61. Williams MD, Murr PC. Laparoscopic insufflation of the abdomen depresses cardiopulmonary function. Surg Endosc 1993;7:12-6. [CrossRef]

62. Diebel LN, Dulchavsky SA, Wilson RF. Effect of increased intra-abdominal pressure on mesenteric arterial and intestinal mucosal blood flow. J Trauma 1992;33:45-8. [CrossRef]

63. Ishizaki Y, Bandai $Y$, Shimomura K, Abe H, Ohtomo Y, Idezuki Y. Changes in splanchnic blood flow and cardiovascular effects following peritoneal insufflation of carbon dioxide. Surg Endosc 1993;7:420-3. [CrossRef]

64. Windsor MA, Bonham MJ, Rumball M. Splanchnic mucosal 
ischemia: an unrecognized consequence of routine pneumoperitoneum. Surg Laparosc Endosc 1997;7:480-2. [CrossRef]

65. Leduc LJ, Mitchell A. Intestinal ischemia after laparoscopic cholecystectomy. JSLS 2006;10:236-8.

66. Hasson HM, Galanopoulos C, Langerman A. Ischemic necrosis of small bowel following laparoscopic surgery. JSLS 2004;8:159-63.

67. Schäfer M, Sägesser H, Reichen J, Krähenbühl L. Alterations in hemodynamics and hepatic and splanchnic circulation during laparoscopy in rats. Surg Endosc 2001;15:1197-201.

68. Gudmundsson FF, Gislason HG, Dicko A, Horn A, Viste A, Grong $\mathrm{K}$, et al. Effects of prolonged increased intra-abdominal pressure on gastrointestinal blood flow in pigs. Surg Endosc 2001;15:854-60. [CrossRef]

69. Polat C, Arikan Y, Vatansev C, Akbulut G, Yilmaz S, Dilek FH, et al. The effects of increased intraabdominal pressure on coIonic anastomoses. Surg Endosc 2002;16:1314-9. [CrossRef]

70. Andrei VE, Schein M, Wise L. Small bowel ischemia following laparoscopic cholecystectomy. Dig Surg 1999;16:522-4.

71. Schoenberg MH, Muhl E, Sellin D, Younes M, Schildberg FW, Haglund U. Posthypotensive generation of superoxide free radicals-possible role in the pathogenesis of the intestinal mucosal damage. Acta Chir Scand 1984;150:301-9.

72. Takada K, Yamashita K, Sakurai-Yamashita Y, Shigematsu K, Hamada Y, Hioki K, et al. Participation of nitric oxide in the mucosal injury of rat intestine induced by ischemia-reperfusion. J Pharmacol Exp Ther 1998;287:403-7.

73. Eleftheriadis E, Kotzampassi K, Papanotas K, Heliadis N, Sarris K. Gut ischemia, oxidative stress, and bacterial translocation in elevated abdominal pressure in rats. World J Surg 1996;20:11-6. [CrossRef]
74. Moncada S, Erusalimsky JD. Does nitric oxide modulate mitochondrial energy generation and apoptosis? Nat Rev Mol Cell Biol 2002;3:214-20. [CrossRef]

75. Dröge W. Free radicals in the physiological control of cell function. Physiol Rev 2002;82:47-95. [CrossRef]

76. Marshall JC, Christou NV, Meakins JL. The gastrointestinal tract. The "undrained abscess" of multiple organ failure. Ann Surg 1993;218:111-9. [CrossRef]

77. Deitch EA. Bacterial translocation or lymphatic drainage of toxic products from the gut: what is important in human beings? Surgery 2002;131:241-4. [CrossRef]

78. Schietroma M, Carlei F, Lezoche E, Agnifili A, Enang GN, Mattucci $S$, et al. Evaluation of immune response in patients after open or laparoscopic cholecystectomy. Hepatogastroenterology 2001;48:642-6.

79. Schietroma M, Carlei F, Mownah A, Franchi L, Mazzotta C, Sozio A, et al. Changes in the blood coagulation, fibrinolysis, and cytokine profile during laparoscopic and open cholecystectomy. Surg Endosc 2004;18:1090-6. [CrossRef]

80. Soybel DI, Zinner MJ. Ileus and the macrophage. Ann Surg 2003;237:316-8. [CrossRef]

81. Hudson JC, Wurm WH, O'Donnell TF Jr, Shoenfeld NA, Mackey WC, Callow AD, et al. Hemodynamics and prostacyclin release in the early phases of aortic surgery: comparison of transabdominal and retroperitoneal approaches. J Vasc Surg 1988;7:190-8. [CrossRef]

82. Cuschieri A. Adverse cardiovascular changes induced by positive pressure pneumoperitoneum. Possible solutions to a problem. Surg Endosc 1998;12:93-4. [CrossRef]

83. Jaffe V, Russell RC. Fatal intestinal ischaemia following laparoscopic cholecystectomy. Br J Surg 1994;81:1827-8. [CrossRef] 